\title{
PARÁMETROS FERMENTATIVOS Y VALOR NUTRICIONAL DE ENSILADOS DE AVENA CON GRANOS DE GIRASOL Y MAÍZ
}

\author{
FERMENTATIVE PARAMETERS AND NUTRITIONAL VALUE OF OAT \\ SILAGE WITH SUNFLOWERS AND CORN GRAINS
}

\author{
Elia E. Araiza-Rosales ${ }^{1}$, Francisco 0. Carrete-Carreón², Faviola Ortiz- \\ Robledo $^{3}$, Juan F. Sánchez-Arroyo ${ }^{2}$ y Esperanza Herrera-Torres ${ }^{3 *}$
}

\begin{abstract}
'CONACYT-FMVZ, Universidad Juárez del Estado de Durango (UJED), Facultad de Medicina Veterinaria y Zootecnia, Durango, Durango, México. ${ }^{2}$ UJED, Facultad de Medicina Veterinaria y Zootecnia, Durango, Durango; México. ${ }^{3}$ Tecnológico Nacional de México, Instituto Tecnológico del Valle del Guadiana, Villa Montemorelos, Durango, México.
\end{abstract}

*Corresponding author (hetoes99@yahoo.m.mx)

\section{SUMMARY}

One of the primary goals of livestock producers is to maintain forage quality at adequate levels that allow obtaining a good profit in milk production. A supplementation strategy could be silage with sources of fat and soluble carbohydrates that improve forage quality. The objective of this study was to evaluate the fermentative and nutritional quality of oat silage with ground corn and sunflower grain (SG) using three combinations of oat forage and ground corn (100-0, 95-5, 90-10) with three levels of sunflower grain $(0,5$ and $10 \%$ ). The $\mathrm{pH}, \mathrm{N}-\mathrm{NH}_{3}$, lactic acid, dry matter (DM), crude protein (CP), crude fat (CF), non-structural carbohydrates (NSC), in vitro digestibility of dry matter (IVDDM), neutral detergent fiber (NDF), acid detergent fiber (ADF) and lignin were evaluated in triplicate using 27 micro-silos. No significant Combination $\times$ SG level interaction was observed $(P>0.05)$. DM content was higher in $\mathrm{T} 2$ whereas $\mathrm{CP}$ concentration was lower in $\mathrm{T} 6(95-5-10)(P \leq 0.05)$. The Combination $\times$ SG level interaction was significant for $C F, A D F$, lignin and IVDMD ( $\mathrm{P} \leq 0.05)$; however, such interaction was non-significant for NDF, $\mathrm{pH}$, $\mathrm{N}-\mathrm{NH}_{3}$ and lactic acid $(\mathrm{P}>0.05)$. The inclusion of $\mathrm{SG}$ when combined with oat forage and ground corn increases the nutritional value of the oat silage but does not improve the fermentative quality of the forage.

Index words: Avena sativa, fermentation, nutritive quality, silage, sunflower.

\section{RESUMEN}

Uno de los principales objetivos de los productores pecuarios es mantener la calidad del forraje a niveles adecuados que permitan obtener una buena ganancia en producción de leche. Una estrategia de suplementación pueden ser los ensilados con fuentes de grasa y carbohidratos solubles que mejoren la calidad del forraje. El objetivo del presente estudio fue evaluar la calidad de fermentación y nutritiva del ensilado de avena con maíz molido y grano de girasol (SG), mediante tres combinaciones de forraje de avena y maíz molido (100-0, 95-5, 90-10) y tres niveles de grano de girasol $(0,5$ y $10 \%$ ). Se determinó el $\mathrm{pH}, \mathrm{N}-\mathrm{NH}_{3}$, ácido láctico, así como materia seca (MS), proteína cruda (PC), grasa cruda (GC), carbohidratos no estructurales (CNE), digestibilidad in vitro de la materia seca (DIVMS), fibra detergente neutra (FDN), fibra detergente ácida (FDA) y lignina en los tratamientos por triplicado, empleando 27 microsilos. No se observó interacción significativa combinación $\times$ nivel de grano $(P>0.05)$. El contenido de MS fue mayor en T2 y la concentración de PC fue menor en T6 (95-5-10) $(P \leq 0.05)$. La interacción combinación $\times$ nivel de SG fue significativa para el contenido de GC, FDA, lignina y DIVMS $(\mathrm{P} \leq 0.05)$; sin embargo, la interacción no fue significativa para $\mathrm{pH}$ y la concentración de $\mathrm{FDN}, \mathrm{N}-\mathrm{NH}_{3}$ y ácido láctico $(\mathrm{P}>0.05)$. La inclusión de grano de girasol cuando se combina con forraje de avena y maíz molido aumenta el valor nutritivo del ensilaje de avena pero no mejora la calidad fermentativa del forraje.

Palabras clave: Avena sativa, calidad nutritiva, ensilaje, fermentación, girasol.

\section{INTRODUCTION}

Northern Mexico has been experiencing extreme temperatures and dry seasons that lead to a reduction in forage production and nutritional quality. Under these production conditions, the use of additives emerges as an alternative in livestock feeding (Herrera-Torres et al., 2014) Additives improve the animal feed intake and productive performance (Garcés et al., 2004); thus, livestock farmers use the silage process for the conservation of forages The silage process is carried out by acidification and fermentation of carbohydrates soluble in lactic acid and volatile fatty acids by lactic acid producing microorganisms under anaerobic conditions; in addition, it inhibits the growth of pathogenic microorganisms and allows the nutritional characteristics of forage to be preserved for later use (Wilkins et al., 1999). Oats is an important forage used in Northern Mexico, it is commonly used for silage as it requires less water for growth and is very useful for late planting when growing conditions do not justify the use of corn crops (Sánchez et al., 2014). Furthermore, oat forage has been shown to be a good forage source for ensiling; however, its metabolizable energy content is relatively low (Condori-Quispe et al., 2019). On the other hand, ground corn is an important ingredient for silage due to its energy content; consequently it is commonly used as an ingredient when ensiling forages (Moscoso-Muñoz et al., 2020; Ortiz et al., 2017). Sunflower is a crop that 
tolerates soil moisture deficit; this characteristic allows it to withstand the shortage of rains and prolonged droughts; in addition, sunflower grain (SG) is rich in crude protein and crude fat (mostly polyunsaturated free fatty acids), which confer the ability to SG of being used as additive (Basarab et al., 2008). Therefore, the objective of this study was to determine the effect of the addition of different proportions of ground corn and sunflower grains on fermentative and nutritional quality of oat silage.

\section{MATERIALS AND METHODS}

\section{Study area}

This study was carried out at Faculty of Veterinary Medicine and Zootechnics, Juárez University of the state of Durango, Mexico. The oat forage (cv. Cuauhtémoc) was randomly harvested from irrigated crops located nearby the Faculty area in Durango, Mexico. Sunflower grain (cv. Madero 31) and ground corn (cv. Caribu) were purchased at a local store. The chemical composition of the ingredients is presented in Table 1 .

\section{Preparation of micro-silos}

Experimental micro-silos were prepared with different proportions of oat forage (OF), sunflower grain (SG) and ground corn (GC). Twenty-seven experimental micro-silos were prepared by mixing solely oat forage $(\mathrm{T} 1)$, and oat forage with ground corn and sunflower grain (T2 to T9) as described in Table 2. Oat forage was harvested at late milk maturity stage (Rosser et al., 2016). Subsequently, forage was cut to a particle size of 2 to $4 \mathrm{~cm}$; afterwards, experimental micro-silos were hermetically sealed into plastic containers $(19 \mathrm{~L})$ for $30 \mathrm{~d}$. Once the time elapsed, the silages were opened for analysis.

\section{Experimental design and experimental unit}

A completely randomized design was used under a $3 \times$ 3 factorial arrangement with three mixtures of oat forage and ground corn, and three levels of sunflower grain, resulting in nine treatments with three replications, The experimental units were the micro-silos.

\section{Silage fermentation analysis}

Once the silages were opened, the following variables were evaluated: $\mathrm{pH}$ was measured according to the method described by Tobía et al. (2004) using a potentiometer (Model HI 83142, Hanna Instruments, Mexico City); lactic acid was evaluated according to Borshchevskaya et al. (2016); ammonia-nitrogen $\left(\mathrm{NH}_{3}-\mathrm{N}\right)$ concentration was evaluated using the procedure proposed by Galyean (2010).

\section{Chemical analyses}

Samples of each experimental micro-silo were dried into a forced-air oven at $55{ }^{\circ} \mathrm{C}$ for $72 \mathrm{~h}$, and ground to $1 \mathrm{~mm}$ particles using a Wiley mill (Arthur $\mathrm{H}$. Thomas, Philadelphia, Pennsylvania, USA) and stored for further analyses. Dry matter and ash were determined by drying the samples according to procedures proposed by AOAC (2015). Crude fat (CF) was calculated by extracting fat using the soxhlet equipment as proposed by AOAC (1990). The CP concentration was calculated by determining the total nitrogen $(\mathrm{N})$ content using the micro-Kjeldhal technique (Method 920.87 ; 5) and multiplied by a fixed conversion factor (6.25) according to AOAC (1990). Neutral detergent fiber (NDF), acid detergent fiber (ADF) and lignin concentrations were determined following methods proposed by Van Soest et al. (1991). Nonstructural carbohydrates (NSC) were estimated as the difference resulted from the equation NSC $=[100-(C P+$ $\mathrm{CF}+$ Ash FDN)]. In vitro dry matter digestibility (IVDMD) at $48 \mathrm{~h}$ was estimated in triplicate by incubating samples

Table 1. Chemical composition of oat forage, corn grain and sunflower grain used in the preparation of microsilos $\left(\mathrm{g} \mathrm{kg}^{-1}\right)$.

\begin{tabular}{lccc}
\hline & Oat forage & Corn grain & Sunflower grain \\
\hline Dry matter & 205 & 855 & 900 \\
Crude protein & 123.5 & 93.1 & 193 \\
NDF & 710.6 & 77.2 & 700.5 \\
ADF & 590.9 & 20.5 & 450.1 \\
Ash & 124.1 & 14.3 & 380 \\
Lignin & 25 & 10.3 & 150 \\
IVDMD & 581.7 & 705.5 & 604.3
\end{tabular}

NDF: neutral detergent fiber, ADF: acid detergent fiber, IVDMD: in vitro digestibility of dry matter 
Table 2. Proportions of the experimental silages.

\begin{tabular}{lccc}
\hline Treatment & Oat forage (\%) & Ground corn (\%) & Sunflower grain (\%) \\
\hline T1 & 100 & 0 & 0 \\
T2 & 100 & 0 & 5 \\
T3 & 100 & 0 & 10 \\
T4 & 95 & 5 & 0 \\
T5 & 95 & 5 & 5 \\
T6 & 95 & 5 & 10 \\
T7 & 90 & 10 & 0 \\
T8 & 90 & 10 & 5 \\
T9 & 90 & 10 & 10 \\
\hline
\end{tabular}

of experimental micro-silos (DaisyII ${ }^{\circledR}$, ANKOM Technology, Fairport, New York, USA) according to procedures described by the manufacturer.

\section{Statistical analysis}

The data were analyzed through analysis of variance using the GLM procedures of SAS version 6 (SAS Institute, 1989) using the model

$$
y i j=\mu+T i+\beta j+(T \beta) i j+£ i j
$$

where: $y i j$ is the response, $\mu$ is the mean, $T i$ is the treatment effect, $\beta j$ is the level of sunflower, (TR)ij is the interaction effect and $£ i j$ is the experimental error.

Means comparison was performed with the Tukey test declaring significant differences at $P \leq 0.05$; highly significant differences were declared at $P \leq 0.01$ and very highly significant differences at $P \leq 0.001$ (Equation 1).

\section{RESULTS AND DISCUSSION}

Table 3 shows the chemical composition of experimental silages. No significant interaction between OF-GC mixtures and SG level was observed $(P>0.05)$. DM content was lower in the mixture 95-5-10 (P $\leq 0.05)$; however, contents of DM registered in this research are into acceptable values for silage of good quality (Mohd-Setapar, et al., 2012); these authors mentioned that silages should contain from 30 to $35 \%$ of DM. Results of this study agree with those obtained by Apráez-Guerrero et al. (2012) who registered values of $28.78 \%$ in oat silage, whereas Ortiz et al. (2017) reported $20.4 \%$ in maralfalfa silage.

Interaction OF-GC $\times$ SG level was significant for protein content $(P \leq 0.05$; Table 3$)$. The lower protein concentration was observed in treatment 95-5-10 ( $\mathrm{P} \leq 0.05)$; however, the protein concentrations registered in this research are within the optimal range according to de Blas et al. (2010) Likewise, Van Soest (1994) mentioned that lower PC values (6-8 \%) in the cattle diet can negatively affect ruminal nitrogen metabolism and feed intake. The protein content obtained in this study was higher than that registered by Abdelhadi and Santini (2006) in corn and sorghum silages (6.1 and $6.37 \%$, respectively), and by Jensen et al. (2005); meanwhile, Castillo et al. (2009) observed a protein content of $10.4 \%$ in corn-bean silage.

Interaction OF-GC $\times$ SG level was very highly significant for CF content ( $P \leq 0.001$; Table 3$)$. The higher content of $\mathrm{CF}$ was observed in silages with sunflower grain. This may be related to the high oil content in SG (42\%) (McGuire and McGuire, 2000). These results indicate that fat content in oat forage is poor and silages are enriched by the addition of GC and SG in all treatments.

Interaction OF-GC $\times$ SG level was highly significant for NSC content ( $P \leq 0.01$; Table 3$)$. The inclusion of $S G$ and GC increased the NSC concentration in silages, which improves energy content and fermentation rate (Amer et al., 2012). On the contrary, a dilution effect in metabolizable energy was observed when OF increased in experimental micro-silos due to the lower contents of NSC. Otherwise, the NSC values registered were lower than those obtained by Araiza-Rosales et al. (2013) in corn silages.

Interaction OF-GC $\times$ SG level was significant for IVDMD $(P \leq 0.01$; Table 3). The IVDMD increased with SG due to the lower degree of lignification of oat forage. Moreover, micro-silos with CG provided soluble carbohydrates which improved digestibility (Aragadvay-Yungán et al., 2015; Ortiz et al., 2017). Additionally, the treatment with the lowest NDF and lignin content has the lowest IVDMD; on 
the contrary, the higher the content of NDF and lignin, the higher the IVDMD. The digestibility of forage also plays an important role in animal production (Li et al., 2014). It is worth mentioning that the IVDMD depends on physical characteristics of forage, especially the fiber content; low NDF and ADF contents lead to a rapid increase in digestibility of DM. This agrees with results obtained in this study and with those reported by Huhtanen et al., 2007 and by Zhang et al., 2016. Regarding to the fiber content in experimental micro-silos, no significant interaction OF-GC $\times$ SG level for NDF was observed ( $P>0.05$; Table 4); however, the values obtained for NDF are in an acceptable range for good quality forage $\left(<60 \mathrm{~g} \mathrm{~kg} \mathrm{DM}^{-1}\right)$. These results may be explained by the increased hydrolysis of hemicellulose that occurs during silage fermentation. At this stage, pentoses are released and may be fermented into lactic and acetic acids (McDonald et al., 2002). Conversely, higher concentrations of NDF were registered by Britos et al. (2007) in pasture silage enriched with buttermilk.

Interaction OF-GC $\times$ SG level was highly significant $(\mathrm{P} \leq$ 0.01; Table 4) for ADF content. The ADF concentration in all microsilos was higher than the optimum value (25\%) as reported by Phiri et al. (2007). The lignin content of SG was relatively high and it is reported to be within 20-25\% according to Taha et al. (2012); in addition, Kimiaeitalab et al. (2017) reported ADF contents of $70 \%$. Due to this, when $S G$ is added an increase in ADF and lignin is observed in the experimental micro-silos; however, IVDMD was not affected by the addition of SG. This can be explained as a possible dilution effect that can be attributable to a reduction in oat forage and an increase in CG.
Interaction OF-GC $\times$ SG level was significant $(P \leq 0.01$; Table 4) for lignin content. The lignin values registered in this study were higher than those reported by Castro et al. (2006) in silage of Tifton 85 (Cynodon spp.) pasture and star grass silage. Moreover, contents of ADF and NDF are 40 and $70 \%$, respectively.

\section{$\mathrm{pH}$ and $\mathrm{N}-\mathrm{NH}_{3}$}

Interaction between OF-GC $\times$ SG level for $\mathrm{pH}, \mathrm{N}-\mathrm{NH}_{3}$ and lactic acid was not significant $(P>0.05$; Table 5); however, the values determined in this study are within the optimal range recommended by Van Soest et al. (1991). Additionally, Evangelista et al. (2000) prepared silages with Cyonodon that presented $\mathrm{pH}$ values of 4.5 to 5.3 which are similar to those obtained in this study; low pH values avoid deterioration. The obtained values can be explained by the low content of soluble carbohydrates ( $\mathrm{Vu}$ et al., 2019) which promotes the production of lactic acid. These results agree with those reported by Aragadvay-Yungán et al. (2015) in sunflower silage.

On the other hand, the highest concentration of $\mathrm{N}-\mathrm{NH}_{3}$ was registered in silage with $10 \%$ SG (100-0-10); this increase can be attributed to the presence of microorganisms capable of improving proteolysis when they adhere to the substrate due to a reduction in the fiber fractions (Berumen et al., 2015). Moreover, this parameter is an indicator of the catabolism of proteins and aminoacids (Junior et al., 2017). The results obtained in this study are similar to those reported by Zanine et al. (2010) in corn silage (14.6 $\%)$, but higher than those mentioned by Ortiz et al. (2017) in maralfafa silages.

Table 3. Chemical composition of experimental silage ( $\left.\mathrm{g} \mathrm{kg} \mathrm{DM}^{-1}\right)$.

\begin{tabular}{lccccc}
\hline Ratio OF-GC × SG (\%) & DM (\%) & CP (\%) & CF (\%) & NSC (\%) & IVDMD (\%) \\
\hline $100-0-0$ & $30.4 \mathrm{ab}$ & $12.0 \mathrm{a}$ & $3.31 \mathrm{~d}$ & $58.9 \mathrm{ab}$ & $51.5 \mathrm{c}$ \\
$100-0-5$ & $32.97 \mathrm{a}$ & $11.8 \mathrm{a}$ & $11.0 \mathrm{a}$ & $55.2 \mathrm{bc}$ & $59.8 \mathrm{c}$ \\
$100-0-10$ & $28.4 \mathrm{ab}$ & $11.1 \mathrm{a}$ & $10.8 \mathrm{a}$ & $54.5 \mathrm{bc}$ & $68.9 \mathrm{ab}$ \\
$95-5-0$ & $29.8 \mathrm{ab}$ & $10.9 \mathrm{a}$ & $3.9 \mathrm{~d}$ & $63.0 \mathrm{a}$ & $64.8 \mathrm{~b}$ \\
$95-5-5$ & $28.9 \mathrm{ab}$ & $11.1 \mathrm{a}$ & $11.6 \mathrm{a}$ & $52.0 \mathrm{c}$ & $65.81 \mathrm{ab}$ \\
$95-5-10$ & $23.7 \mathrm{c}$ & $8.5 \mathrm{~b}$ & $9.7 \mathrm{ab}$ & $54.5 \mathrm{bc}$ & $70.87 \mathrm{ab}$ \\
$90-10-0$ & $26.6 \mathrm{bc}$ & $11.5 \mathrm{a}$ & $5.6 \mathrm{c}$ & $56.4 \mathrm{bc}$ & $71.5 \mathrm{a}$ \\
$90-10-5$ & $30.1 \mathrm{ab}$ & $10.8 \mathrm{a}$ & $5.8 \mathrm{c}$ & $57.3 \mathrm{~b}$ & $69.6 \mathrm{ab}$ \\
$90-10-10$ & $28.3 \mathrm{ab}$ & $11.9 \mathrm{a}$ & $10.4 \mathrm{a}$ & $54.2 \mathrm{bc}$ & $70.6 \mathrm{ab}$ \\
SEM & 0.40 & 0.19 & 0.21 & 0.32 & 0.55 \\
OF-GC $\times$ SG & $\mathrm{NS}$ & $*$ & $* * *$ & $* *$ & $* *$ \\
\hline
\end{tabular}

Different letters within a column indicates significant differences (Tukey, $P \leq 0.05$ ). $*: P \leq 0.05, * *: P \leq 0.01, * * *: P \leq 0.001, N S$ : non significant difference, DM: dry matter, CP. crude protein; CF: crude fat, NSC: non-structural carbohydrates, IVDMD: in vitro dry matter digestibility, SEM: standard error of the mean. 
Table 4. Detergent fibers content of oat silages with different levels of ground corn and sunflower grain ( $\left.\mathrm{g} \mathrm{kg} \mathrm{DM}^{-1}\right)$.

\begin{tabular}{lccc}
\hline Ratio OF-GC × SG (\%) & NDF (\%) & ADF (\%) & LIG (\%) \\
\hline $100-0-0$ & $51.5 \mathrm{~b}$ & $36.3 \mathrm{~b}$ & $5.0 \mathrm{c}$ \\
$100-0-5$ & $54.7 \mathrm{ab}$ & $42.9 \mathrm{a}$ & $6.9 \mathrm{bc}$ \\
$100-0-10$ & $55.2 \mathrm{ab}$ & $43.6 \mathrm{a}$ & $10.7 \mathrm{ab}$ \\
$95-5-0$ & $59.5 \mathrm{a}$ & $43.4 \mathrm{a}$ & $12.6 \mathrm{a}$ \\
$95-5-5$ & $57.8 \mathrm{ab}$ & $39.0 \mathrm{ab}$ & $12.8 \mathrm{a}$ \\
$95-5-10$ & $52.4 \mathrm{~b}$ & $34.4 \mathrm{ab}$ & $10.8 \mathrm{ab}$ \\
$90-10-0$ & $58.0 \mathrm{ab}$ & $33.3 \mathrm{~b}$ & $14.8 \mathrm{a}$ \\
$90-10-5$ & $55.3 \mathrm{ab}$ & $35.6 \mathrm{~b}$ & $12.2 \mathrm{a}$ \\
$90-10-10$ & $54.8 \mathrm{ab}$ & $32.6 \mathrm{~b}$ & $13.36 \mathrm{a}$ \\
SEM & 0.39 & 0.41 & 0.32 \\
OF-GC $\times$ SG & NS & $* *$ & $* *$ \\
\hline
\end{tabular}

Means with different letters within a same column indicates significant differences (Tukey, $\mathrm{P} \leq 0.05)$. **: $\mathrm{P} \leq 0.01$, NS: non significant, SEM: standard error of the mean, NDF: neutral detergent fiber, ADF: acid detergent fiber, LIG: lignin.

Table 5. Fermentative parameters of oat silage with different levels of ground corn and sunflower grain ( $\left.\mathrm{g} \mathrm{kg} \mathrm{DM}^{-1}\right)$.

\begin{tabular}{lccc}
\hline Ratio OF-GC × SG (\%) & $\mathrm{pH}$ & $\mathrm{NH}_{3}$-N/total N & Lactic acid (\%) \\
\hline $100-0-0$ & $4.2 \mathrm{a}$ & $7.7 \mathrm{c}$ & $0.8 \mathrm{~d}$ \\
$100-0-5$ & $4.3 \mathrm{a}$ & $9.3 \mathrm{bc}$ & $1.0 \mathrm{~d}$ \\
$100-0-10$ & $4.3 \mathrm{a}$ & $12.9 \mathrm{a}$ & $1.2 \mathrm{~d}$ \\
$95-5-0$ & $4.2 \mathrm{a}$ & $11.9 \mathrm{ab}$ & $1.1 \mathrm{~d}$ \\
$95-5-5$ & $4.3 \mathrm{a}$ & $11.3 \mathrm{ab}$ & $1.5 \mathrm{~b}$ \\
$95-5-10$ & $4.3 \mathrm{a}$ & $7.4 \mathrm{c}$ & $1.6 \mathrm{~b}$ \\
$90-10-0$ & $4.2 \mathrm{a}$ & $7.3 \mathrm{c}$ & $1.3 \mathrm{~b}$ \\
$90-10-5$ & $4.2 \mathrm{a}$ & $9.9 \mathrm{bc}$ & $1.3 \mathrm{~b}$ \\
$90-10-10$ & $4.2 \mathrm{a}$ & $9.7 \mathrm{bc}$ & $1.8 \mathrm{a}$ \\
SEM & 0.03 & 0.24 & 0.1 \\
OF-GC $\times$ SG & $\mathrm{NS}$ & $\mathrm{NS}$ & $\mathrm{NS}$ \\
\hline
\end{tabular}

Differents letters within a column indicates significant differences (Tukey, $\mathrm{P} \leq 0.05$ ). $*: \mathrm{P} \leq 0.05, * *: \mathrm{P} \leq 0.01, * * *: \mathrm{P} \leq 0.001$, NS: non significant, SEM: standard error of the mean.

The highest concentration of lactic acid was registered in the treatments whit $10 \%$ of ground corn as well as in treatments where SG was added. The values of lactic acid in this study are considered as adequate (Kung and Shaver, 2001) and may guarantee a good fermentation of forage (Schroeder, 2004). Moreover, the concentrations registered in this study were higher than those reported by ApráezGuerrero et al. (2012) in oat forage silages.

\section{CONCLUSIONS}

The inclusion of sunflower grain increases the nutritional value of oat silage when oat forage and ground corn are combined; however, the fermentative quality is not improved.

\section{BIBLIOGRAPHY}

Abdelhadi L. 0. and F. J. Santini (2006) Corn silage versus grain sorghum silage as a supplement to growing steers grazing high quality pastures: effects on performance and ruminal fermentation. Animal Feed Science and Technology 127:33-43, https://doi. org/10.1016/j.anifeedsci.2005.08.010

Amer S., F. Hassanat, R. Berthiaume, P. Seguinc and A. F. Mustafaa (2012) Effects of water soluble carbohydrate content on ensiling characteristics, chemical composition and in vitro gas 
production of forage millet and forage sorghum silages. Animal Feed Science and Technology 177:23-29, https://doi. org/10.1016/j.anifeedsci.2012.07.024

AOAC, Association of Official Analytical Chemists (1990) Official Methods of Analysis. 15th edition. Association of Official Analytical Chemists. Washington D. C., USA. 771 p.

Apráez-Guerrero J. E., E. G. Insuasty-Santacrúz, J. E. Portilla-Melo y W. A. Hernández-Vallejo (2012) Composición nutritiva y aceptabilidad del ensilaje de avena forrajera (Avena sativa), enriquecido con arbustivas: acacia (Acacia decurrens), chilca (Braccharis latifolia) y sauco (Sambucus nigra) en ovinos. Revista Veterinaria y Zootecnia 6:25-35.

Aragadvay-Yungán R. G., A. A. Rayas A., D. Heredia-Nava, J. G. EstradaFlores, E. Martínez-Castañeda y C. M. Arriaga-Jordán (2015) Evaluación in vitro del ensilaje de girasol (Helianthus annuus L.) solo y combinado con ensilaje de maíz. Revista Mexicana de Ciencias Pecuarias 6:315-327, https://doi.org/10.22319/rmcp. v6i3.4094

Araiza-Rosales E. E., E. Delgado-Licón, F. O. Carrete-Carreón, H. MedranoRoldán, A. Solís-Soto, M. Murillo-Ortiz y C. U. Haubi-Segura (2013) Degradabilidad ruminal in situ y digestibilidad in vitro de diferentes formulaciones de ensilados de maíz-manzana adicionados con melaza. Revista Avances en Investigación Agropecuaria 17:79-96.

Basarab J. A., J. L. Aalhus, M. A. Shah, P.S . Mir, V. S. Baron, M. Dugan, E. K. Okine and W. M. Robertson (2007) Effect of feeding sunflower seeds on the performance, carcass characteristics, meat quality, retail stability and sensory characteristics of pasturefed and feedlot finished beef. The Canadian Veterinary Journal 87:15-27, https://doi.org/10.4141 / A06-047

Berumen H. L., J. Páez, N. O. Soto, M. Murillo, E. Herrera and A. Muro (2015) Chemical composition, in vitro gas production and energy value of prickly pear fermented with and without Kluyveromyces marxianus. Journal of BioScience and Biotechnolology 4:359364.

Borshchevskaya L. N., T. L. Gordeeva, A. N. Kalinina and S. P. Sineokii (2016) Spectrophotometric determination of lactic acid. Journal of Analytical Chemistry 71:755-758, https://doi.org/10.1134/ s1061934816080037

Britos A., J. Repetto, D. Garciarena y C. Cajarville (2007) Efecto del suero de queso como aditivo de ensilajes de pastura sobre la conservación, los azucares solubles y la producción de gas in vitro. Agrociencia 11: 2:72-77.

Castillo J. M., A. Rojas-Bourrillón y R. WingChing-Jones (2009) Valor nutricional del ensilaje de maíz cultivado en asocio con vigna (Vigna radiata). Agronomía Costarricense 33:133-146.

Castro F. G. F., L. G. Nussio, C. M. Haddad, F. P. de Campos, R. M. Coelho, L. J. Mari e P. A. Toledo (2006) Características de fermentação e composição químico-bromatológica de silagens de capimTifton 85 confeccionadas com cinco teores de matéria seca. Revista Brasileira de Zootecnia 35:7-20, https://doi. org/10.1590/S1516-35982006000100002

Condori-Quispe R., M. G. Loza-Murguía, C. Achu-Nina y H. Alberto-Alberto (2019) Calidad del ensilaje de avena forrajera (Avena sativa L.) conservado en tres diferentes tipos de silos artesanales. Journal of the Selva Andina Animal Science 6:57-65, https://doi. org/10.36610/j.jsaas.2019.060200057

de Blas C., P. García-Rebollar, M. Gorrachategui y G. G. Mateos (2010) Tablas FEDNA de Composición y Valor Nutritivos de Alimentos para la Fabricación de Piensos Compuestos. 3a edición. Fundación Española para el Desarrollo de la Nutrición Animal. Madrid, España. 502 p.

Evangelista A. R., J. A. de Lima e T. F. Bernardes (2000) Avaliação de algumas características da silagem de gramínea Estrela Roxa (Cynodon nlemfuensis Vanderyst). Revista Brasileira de Zootecnia 29:941-946, https://doi.org/10.1590/S151635982000000400001

Galyean M. L. (2010) Laboratory Procedures for Animal Nutrition Research. 14th edition. Departament of Animal and Food Sciences, Texas Tech University. Lubbock, Texas, USA. 189 p.

Garcés M. A. M., L. Berrio R., S. Ruiz A., J. G. Serna L. y A. F. Builes A. (2004) Ensilaje como fuente de alimentación para el ganado. Revista Lasallista de Investigación 1:66-71.
Herrera-Torres E., M. Murillo, L. Berumen, J. Páez y G. Villarreal (2014) Efecto de Sacharomyces cerevisiae y Kluyveromices marxianus durante el tiempo de fermentación en la calidad nutritiva del nopal forrajero. Ecosistemas y Recursos Agropecuarios 1:3340.

Huhtanen P., M. Rinne and J. Nousiainen (2007) Evaluation of the factors affecting silage intake of dairy cows: a revision of the relative silage dry-matter intake index. Animal 1:758-770, https://doi. org/10.1017/S175173110773673X

Jensen C., M. R. Weisbjerg, P. Nørgaard and T. Hvelplund (2005) Effect of maize silage maturity on site of starch and NDF digestion in lactating dairy cows. Animal Feed Science and Technology 118:279-294, https://doi.org/10.1016/j.anifeedsci.2004.10.011

Junior M. C., C. C. Jobim, M. P. Osmri and T. T. Tres (2017) Nutritional additives in high moisture corn silage. Agrária - Revista Brasileira de Ciências Agrárias 12:105-111, https://doi.org/10.5039/agraria. v12i1a5413

Kimiaeitalab M. V., L. Cámara, S. Mirzae Gourdazi, E. Jiménez-Moreno and G. G. Mateos (2017) Effects of the inclusion of sunflower hulls in the diet on growth performance and digestive tract traits of broilers and pullets fed a broiler diet from zero to $21 \mathrm{~d}$ of age. A comparative study. Poultry Science 96:581-592, https://doi. org/10.3382/ps/pew263

Kung L. and R. Shaver (2001) Interpretation and use of silage fermentation analysis reports. Focus on Forage 3:1-5

Li M., H. Zhow, G. Hou and Y. Kie (2014) Effects of sucrose, glucose, molasses and cellulose on fermentation quality and in vitro gas production of king grass silage. Animal Feed Science and Technology 197:206-212, https://doi.org/10.1016/j. anifeedsci.2014.06.016

McDonald P., R. A. Edwards and J. F. Greenhalgh (2002) Animal Nutrition. 6th edition. Longman. London, UK. $543 \mathrm{p}$.

McGuire M. A. and M. K. McGuire (2000) Conjugated linoleic acid (CLA): a ruminant fatty acid with beneficial effects on human health. Journal of Animal Science 77 Suppl. E:1-8, https://doi. org/10.2527/jas2000.00218812007700ES0033x

Mohd-Setapar H., N. Abd-Talib and R. Azis (2012) Review on crucial parameters of silage quality. APCBEE Procedia 3:99-103, https://doi.org/10.1016/j.apcbee.2012.06.053

Moscoso-Muñoz J. E., O. Gomez-Quispe y V. Guevara-Carrasco (2020) Contenido de energía metabolizable y energía neta del maíz, subproducto de trigo, harina de soya, harina de pescado y aceite de soya para pollos de carne. Scientia Agropecuaria 11:335-344, https://doi.org/10.17268/sci.agropecu.2020.03.05

Ortiz R. F., O. Reyes E., F. O. Carrete C., J. F. Sánchez A., E. Herrera T., M. Murillo 0 . and R. Rosales S. (2017) Nutritional and fermentative quality of maralfalfa (Pennisetum sp.) silages at different cutting ages and ground corn levels. Revista de la Facultad de Ciencias Agrarias UNCUYO 49:345-353

Phiri M. S., N. T. Ngongoni, B. V. Maasdorp, M. Ttiterton, J. F. Mupangwa and A. Sebata (2007) Ensiling characteristics and feeding value of silage made from browse tree legume-maize mixtures. Tropical and Subtropical Agroecosystems 3:149-156.

Rosser C. L., A. D. Beattie, H. C. Block, J. J. Mckinnon, H. A. Lardner, P. Górka and G. B. Penner (2016) Effect of maturity at harvest for whole-crop barley and oat on dry matter intake, sorting, and digestibility when fed to beef cattle. Journal of Animal Science 94:697-708, https://doi.org/10.2527/jas.2015-0063

Sánchez G. R. A., H. Gutiérrez B., A. Serna P., R. Gutiérrez L. y A. Espinoza C. (2014) Producción y calidad de forraje de variedades de avena en condiciones de temporal en Zacatecas, México. Revista Mexicana de Ciencias Pecuarias 5:131-142, https://doi org//10.22319/rmcp.v5i2.3220

SAS Institute (1989) SAS/STAT User's Guide. Version 6, 4th edition. SAS Institute, Inc. Cary, North Carolina, USA. 1848 p.

Schroeder J. W. (2004) Silage fermentation and preservation. NDSU Extension Service. North Dakota State University. Fargo, North Dakota, USA. 8 p

Taha F. S., S. M. Wagdy, M. M. M. Hassanein and S. F. Hamed (2012) Evaluation of the biological activity of sunflower hull extracts. Grasas $y$ Aceites 63:184-92, https://doi.org/10.3989/gya.072111

Tobía C., A. Rojas, E. Villalobos, H. Soto y L. Uribe (2004) Sustitución parcial del alimento balanceado por ensilaje de soya y su efecto en la 
producción y calidad de la leche de vaca, en el trópico húmedo de Costa Rica. Agronomía Costarricense 28:44-47.

Van Soest P. J. (1994) Nutritional Ecology of the Ruminant. 2nd edition. Cornell Univesity Press. Ithaca, New York, USA. 476 p.

Van-Soest P. V., J. B. Robertson and B. A Lewis (1991) Methods for dietary fiber, neutral detergent fiber, and non-starch polysaccharides in relation to animal nutrition. Journal of Dairy Science 74:35833597, https://doi.org/10.3168/jds.s0022-0302(91)78551-2

Vu V. H., X. Li, M. Wang, R. Liu, G. Zhang, W. Liu, B. Xia and Q. Sun (2019) Dynamics of fungal community during silage fermentation of elephant grass (Pennisetum purpureum) produced in northern Vietnam. Asian-Australasian Journal of Animal Science 32:9961006, https://doi.org/10.5713/ajas.18.0708

Wilkins R. J., L. Syrjala-Qvist and K. K. Bolsen (1999) The future role of silage in sustainable animal production. In: Silage Production in
Relation to Animal Performance, Animal Health, Meat and Milk Quality. Proceedings of the XII International Silage Conference, 5-7 July 1999. T. Pauly (ed.). Swedish University of Agricultural Sciences. Uppsala, Sweden. pp:23-40.

Zanine A. M., E. M. Santos, J. R. R. Dórea, P. A. S. Dantas, T. C. da Silva and O. G. Pereira (2010) Evaluation of elephant grass silage with the addition of cassava scrapings. Revista Brasileira de Zootecnia 39:2611-2616, https://doi.org/10.1590/S1516 35982010001200008

Zhang Q., Z. Yu, H. Yang and R. S. Na (2016) The effect of stage of growth and additives with or without cellulose on fermentation and in vitro degradation characteristics of Leymus chinensis silage. Grass and Forage Science 71:595-606, https://doi org/10.1111/gfs. 12210 
